Doi: https://doi.org/10.24036/jep/vol3-iss1/375

\title{
Peningkatan Keterampilan Berargumentasi Ilmiah Pada Siswa Melalui Model Pembelajaran Argument- Driven Inquiry (ADI)
}

\author{
Eni Sumanti Nasution \\ Dosen Prodi Pendidikan Fisika, Universitas Graha Nusantara \\ enisumanti.nst@gmail.com
}

\begin{abstract}
Destination of research to analyze increased students' scientific argumentative ability by way of Argument-Driven Inquiry (ADI) learning model in SMA Negeri 1 Batang Angkola. The study was conducted in a quasi-experiment manner. As for population of the research was students of class $X$ SMAN 1 Batang Angkola. Sample selection that has been used by cluster random sampling, namely class $X I P A_{1}$ and $X I P A_{2}$. This research instrument uses a valid and reliable Learning Outcomes test. The data in this study were analyzed by $T$ - test. The results of the study obtained differences in values of scientific argumentation skills in students through argument-driven inquiry learning model at 76.6 and conventional learning 70.06, this means that there is an influence of students' scientific argumentation skills using the Argument Driven Inquiry learning model more improved compared to using conventional learning.
\end{abstract}

Keywords : Argument Driven Inquiry Learning Model, Scientific Argumentation

This is an open access article distributed under the Creative Commons 4.0 Attribution License, which permits unrestricted use, distribution, and reproduction in any medium, provided the original work is properly cited. $@ 2019$ by author and Universitas Negeri Padang.

\section{PENDAHULUAN}

Pengembangan sumber daya manusia di Indonesia sudah dilakukan dengan bermacammacam cara dimana paling utama dilakukan melalui pendidikan. Adapun sasaran yang diterapkan untuk mendorong kemampuan peserta didik dalam menghasilkan karya kontekstual di dunia pendidikan yang perlu ditingkatkan salah satunya adalah keterampilan melalui fisikal (hardskill) dan keterampilan melalui mental (Softskill) (Permendikbud No 22 tahun 2016).

Adapun yang dilakukan dalam mewujudkan keterampilan yang harus dimiliki pada abad 21 dalam dunia pendidikan adalah dengan dikembangkannya kurikulum 2013. Peningkatkan keterampilan siswa baik keterampilan melalui fisikal (hardskill) maupun keterampilan melalui mental (sofskill) yang termuat dalam kurikulum revisi 2013 dapat dilaksanakan dengan cara 5 M yaitu mengamati, menanya, mencoba, menganalisis dan mengkomunikasikan (Kemendikbud, 2013). Hal ini berkaitan dengan yang terdapat dalam AACTE (2010) yang menyatakan di dalam berkomunikasi untuk argumentasi pada abad ke21 salah satu yang diperlukan oleh siswa dalam suatu pembelajaran adalah kemampuan softskill..
Pemberdayaan dalam melakukan pem belajaran sains agar pengetahuan literasi sains pada siswa meningkatkan dapat diterapkan dengan menggunakan keterampilan berargumentasi. Ditinjau dari aspek penting literasi sains yaitu memahami dan menerapkan keterampilan beragumen tasi ilmiah pada siswa (Simon et al:2006). Adapun pendapat yang dikemukan oleh Duschl \& Osborne (2002) yang mengatakan bahwa hal yang mendasar bagi siswa dalam proses pembelajaran untuk mengetahui bagai mana mendapatkan suatu hasil, peng ujian, dan evaluasi suatu teori dan ber komunikasi seperti seorang ilmuwan sejati menjadi hal utama dalam suatu keterampilan berargumentasi.

Berdasarkan hasil peninjauan dalam proses kegiatan belajar-mengajar fisika di SMA Negeri 1 Batang Angkola Kabupaten Tapanuli Selatan belum ada kemampuan dalam melakukan keterampilan berargumen tasi siswa dimana $40 \%$ tidak pernah mengetahui bagaimana penerapan dalam melakukan kegiatan keterampilan argumen tasi. Permasalahan tersebut tidak lepas dari sistem pembelajaran yang diselenggarakan di SMA Negeri 1 Batang Angkola kurang dapat mengakomodasi argumentasi ilmiah siswa. Proses pembelajaran yang diterapkan ialah pendekatan pembelajaran berpusat guru yaitu bersifat mentransfer konsepkonsep secara langsung kepada siswa dengan 
cara sekedar penyampaian fakta, konsep kepada siswa, tanpa memfasilitasi siswa bagaimana memperoleh konsep/ prinsip fisika tersebut melalui kegiatan sains. Hal ini disebabkan kurangnya kemampuan guru untuk membuat kegiatan di laboratorium seperti membuat Lembar Kegiatan Siswa (LKS).

Argumentasi dapat dikatakan sebagai proses untuk memperjelas atau memperkuat klaim dengan melakukan analisis melalui berpikir kritis dengan disertai bukti-bukti yang memiliki fakta atau keadaan objektif yang diakui kebenarannya dan memiliki alasan yang logis (Inch et al dalam Sukma, 2015). Keterampilan argumentasi dapat dilihat melalui indikator, salah satunya indikator yang mendefinisikan argumen sebagai pernyataan yang disertai alasan yang meliputi komponen klaim atau gagasan (claim), selanjutnya harus dibuktikan dengan data (graound/data), dalam menjembatani antara pernyataan dan data digunakanlah pembenaran (warrant), unsur syarat (qualifer) digunakan ketika pembenaran tidak dapat diterima, dukungan (backing), dan sanggahan (rebuttal) (Toulmin, 2003).

Selain itu, argumentasi memiliki peranan dalam kegiatan belajar-mengajar sains yang dilaksanakan dikelas dapat dikategorikan kedalam lima dimensi. Ada pun dimensi pertama yaitu karakteristik dalam kinerja para ahli yang menjadi gambaran bagi siswa dimana dalam ber argumentasinya dapat menyokong eksistensi proses kognitif dan metakogntif siswa. Selanjutnya untuk dimensi kedua, kompetensi dalam berkomunikasi dan cara berpikir kritis didukung dalam per kembangan kompetensi siswa. Dimensi ketiga, kontribusi dalam perolehan literasi sains untuk dapat digunakan siswa dalam pelatihan berbicara dan menulis melalui bahasa sains. Tahap selanjutnya adalah dimensi ke empat yang mendorong enkulturasi yang dilaksanakan dalam praktek budaya ilmiah serta meningkatkan tahapan epistemik dalam mengetahui bagaimana hasil dari pengetahuan siswa. Tahap akhir adalah dimensi kelima, yang mana pengetahuan dikembangkan melalui penalar an yang mana kriteria nasional didasarkan kepada pemilihan topik atau penentuan sikap dari siswa tersebut (Erduran dalam Marhamah et al:2017).

Adapun cara yang dapat dilaksanakan untuk menanggulangi rendahnya dalam memperoleh nilai keterampilan argumentasi siswa terhadap pembelajaran fisika adalah dengan menggunakan suatu inovasi baru dikelas melalui suatu model pembelajaran. Proses kegiatan pembelajaran dalam melaku kan inovasi yang meningkatkan keaktifan dalam kegiatan belajar-mengajar terutama dalam kegiatan laboratorium yang mana dalam kegiatan ini dapat melatih kognitif siswa dalam berargumentasi. Adapun pembelajaran yang dapat digunakan dalam meningkatkan dan melatih keterampilan berargumentasi siswa digunakah model Argument-Driven Inquiry (ADI). Salah satu yang mendorong peserta didik melakukan kegiatan eksperimen yang mana nantinya siswa dapat meningkatkan pemahaman konsep penting dan praktis dalam pembelajaran IPA adalah dengan mengguna kan model pembelajaran Argument-Driven Inquiry yang merupakan pengembangan dari model pembelajaran inkuri berbasis laboratorium, Hasnunidah (dalam Zahara: 2018),

$$
\text { Kegiatan pembelajaran dengan }
$$
menggunakan model Argument-Driven Inquiry (ADI) memiliki langkah-langkah dalam pelaksanaan pembelajaran. Adapun langkahlangkah model pembelajaran Argument-Driven Inquiry (ADI) 1) Identifikasi tugas yang menciptakan kebutuh an bagi siswa untuk memahami fenomena atau memecahkan masalah; 2) generasi dan analisis data oleh kelompok kecil siswa menggunakan metode desain mereka sendiri; 3) produksi argumen tentatif oleh masing-masing kelompok itu mengartikulasikan dan membenarkan penjelasan dalam media itu dapat dibagikan dengan orang lain; 4) sesi argumentasi di mana masing-masing kelompok membagikan argumennya dan kemudian mengkritik dan menyempurnakan penjelasannya; 5) laporan investigasi yang ditulis oleh masing-masing siswa itu menjelaskan tujuan pekerjaan dan metode yang digunakan, dan memberikan argumen yang beralasan; 6) kaji balik sejawat dari laporan ini untuk memastikan kualitas dan menghasilkan umpan balik berkualitas tinggi untuk individu penulis; 7) revisi selanjutnya dari laporan berdasarkan hasil dari peer review; dan 8 diskusi eksplisit dan reflektif tentang penyelidikan (Sampson et al:2010).

Penggunaan model pembelajaran Argument-Driven Inquiry (ADI) memiliki 
kelabihan dalam proses pembelajarannya. Adapun kelebihan dalam model pembelajaran ini adalah 1) penyelesaian masalah dalam pengembangan untuk memahami dan mengevaluasi fenomena alam dalam melakukan penejleasan ilmiah yang nanti dapat dibingkai untuk mencapai tujuan dari suatu kegiatan kelas, 2) peserta didik dapat diikutsertakan dalam melakukan penelitian atau pencarian suatu masalah, 3) bagian dari proses penyelidikan yang mana digunakan untuk mendorong dalam mendapatkan suatu penjelasan dalam suatu pernyataan ilmiah dalam mendorong individu untuk belajar mendapatkan argumentasi yang mengartikulasikan dan membenarkan, 4) peserta didik diberikan peluang untuk dapat belajar dalam mengusulkan suatu ide, memberikan suatu dukungan berupa data, melakukan penilaian, merevisi ide dengan cara melakukan diskusi dan penulisan yang lebih dapat menghasilkan suatu karya, 5) menghasilkan suatu karya dan dapat dilakukan dengan melakukan suatu komunitas di dalam kelas yang mana dapat memberikan bukti kemudian dapat memberikan pemikiran kritis, 6) pengambilan kendali dalam pembelajaran perorangan yang dapat didorong kepada siswa (Amin dan Corebima :2016)

Kegiatan belajar-mengajar terutama dalam kegiatan laboratorium dengan penggunaan model pembelajaran Argument-Driven Inquiry (ADI) diinginkan agar nantinya dapat membantu siswa untuk terlibat aktif dengan cara melalui merumuskan suatu masalah didalam penyelidikan dapat meningkat. Pembelajaran yang dirancang dengan tahapan yang digunakan dalam model pembelajaran ADI dapat dipastikan siswa memiliki suatu kesempatan dalam kegiatan praktikum selama penyelidikan masalah di laboratorium, dimana dalam kegiatan ini siswa dapat menerima suatu umpan balik selama proses kegiatan pembelajaran berlangsung, siswa juga diberikan bimbingan eksplisit sehingga siswa dapat terlibat langsung (Sampson et al. :2012).

Berdasarkan paparan dari suatu permasalahan yang didapatkan oleh peneliti dari latar belakang penelitian, maka diperoleh suatu rumusan masalah yaitu Apakah peningkatan keterampilan berargumentasi ilmiah pada siswa yang menerapkan model pembelajaran Argument-Driven Inquiry (ADI) lebih baik dibanding dengan pembelajaran konvensional di SMAN 1 Batang Angkola?
Pada hakekatnya tujuan dari penelitian yang dilaksankan adalah menganalisis peningkat an keterampilan berargumentasi ilmiah pada siswa yang menerapkan model pembelajaran Argument-Driven Inquiry (ADI) lebih baik dibandingkan dengan pembelajaran konven sional di SMA Negeri 1 Batang Angkola.

\section{METODE}

Subjek dalam penelitian ini adalah peserta didik di kelas X IPA $\mathrm{Pan}_{1}$ X IPA 2 SMA Negeri 1 Batang Angkola dengan yang masingmasing jumlah siswanya satu kelas adalah 30 siswa. Sedangkan penggunaan metode penelitian nya adalah quasi eksperiment, yang melibatkan dua kelas yaitu X IPA 1 sebagai kelas eksperimen dan X IPA 2 sebagai kelas kontrol. Pengambilan sampel menggunakan teknik cluster random sampling.

Instrumen yang digunakan adalah menggunakan tes essay dengan jumlah soal adalah 15 setelah di validasi. Soal 15 tersebut diujicobakan kepada siswa yang lebih tinggi dan dari hasil yang diperoleh terdapat 10 buah soal yang valid dan untuk soal yang tidak valid terdapat 5 buah soal yang tidak valid dimana nantinya dalam penelitian tidak digunakan. Dalam perhitungan untuk validasi data digunakan dengan SPSS 21 dengan Pearson Correlation Tahap selanjutnya digunakan reliabilitas data, tingkat dalam kesukaran butir soal, daya pembeda butir soal.

Rancangan penelitian ini didesain control grup pretes-postes design seperti ter-dapat dalam Tabel 1.

Tabel 1. Control Grup Pretes-Postes Desaign (Arikunto:2010)

\begin{tabular}{|l|l|l|l|}
\hline Kelas & Pretest & Perlakukan & Postest \\
\hline Experimen & $\mathrm{Y}_{\mathrm{a}}$ & $\mathrm{X}_{\mathrm{a}}$ & $\mathrm{Y}_{\mathrm{b}}$ \\
\hline Kontrol & $\mathrm{Y}_{\mathrm{a}}$ & $\mathrm{X}_{\mathrm{b}}$ & $\mathrm{Y}_{\mathrm{b}}$ \\
\hline
\end{tabular}

Keterangan :

$\mathrm{X}_{\mathrm{a}}$ : Perlakuan pada kelas dalam kelompok eksperimen yaitu model pembelajaran Argument-Driven Inquiry (ADI)

$\mathrm{X}_{\mathrm{b}}$ : Perlakuan berupa pada kelas kontrol yaitu konvensional

$\mathrm{Y}_{\mathrm{a}}$ : Pretest pada kelompok kelas eksperimen dan kelompok kelas kontrol yang diberikan dimana sebelum dilakukan tindakan pembelajaran

$\mathrm{Y}_{\mathrm{b}}$ : Postes pada kelompok kelas eksperimen dan kelompok kelas kontrol yang diberikan 
dimana sesudah dilakukan tindakan pembelajaran

Teknik pengumpulan instumen yang digunakan dalam penelitian ini adalah instrumen dalam melakukan pembelajaran ketika penelitian dan instrumen untuk mengambil data ketika berlangsungnya ataupun sesudah dilakukan penelitian. Adapun alat dalam proses belajarmengajar menggunakan silabus pada materi fisika kelas X ketika berlangsung dalam semester 2, Rencana Pelaksanaan Pembelajaran (RPP), dan lembar kegiatan siswa yang dilakukan melalui praktikum. Pada pengambilan data digunakan istrumen tes keterampilan berargumentasi ilmiah pada siswa.

Adapun bagan dari pelaksanaan penelitian adalah Gambar 1 dibawah berikut ini:

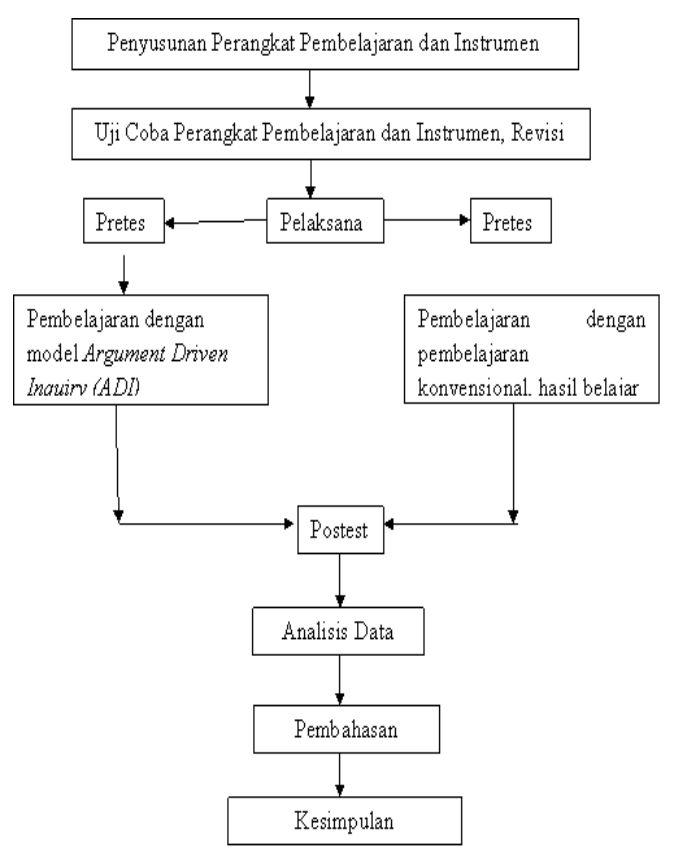

Gambar 1. Tahapan Kegiatan Penelitian

Ada tiga tahapan dalam alur penelitian ini. Tahap persiapan dilakukan dengan melakukan observasi terhadap suatu sekolah yang ingin diteliti, didalam kegiatan observasi maka instrumen yang perlu disiapkan adalah bahan ajar yang meliputi soal keterampilan ber argumentasi siswa, lembar kegiatan siswa. Setelah itu di berikan kepada siswa yang lebih tinggi untuk divalidasikan. Tahap kedua pelaksanaan, dalam tahap ini siswa terlebih dahulu dilakukan pretest sebelum perlakuan untuk mengetahui kemampuan awal siswa, setelah itu diberikan perlakuan kepada masingmasing kelas kemudian dilaksanakan postest untuk mengetahui perngaruh dari model pembelajaran yang digunakan. Tahap ketiga adalah analisis data, setelah dilakukan akhir pada tes maka dilakukanlah analisis data berupa analisis data ketika dilakukan sebelum perlakuan atau sesudah dilakukan perlakuan kepada siswa SMAN 1 Batang Angkola, disamping itu juga digunakan juga uji hipotesis kepada siswa untuk mengetahui pengaruh model pembelajaran yang digunakan. Adapun analisis data ini digunakan program aplikasi Software SPSS 21 dan juga program aplikasi excel.

\section{HASIL DAN PEMBAHASAN}

Pelaksanaan di dalam penelitian ini adalah di SMA Negeri 1 Batang Angkola pada kelas X Tahun Ajaran 2018/2019 semester II. Adapun design atau rancangan dalam penelitian ini menggunakan jenis penelitian quasi eksperi ment. Jenis penelitian ini melibatkan dua kelas yang homogen sampelnya yaitu terdiri dari kelas $\mathrm{X}_{2} \quad \mathrm{IPA}_{2}$ merupakan kelas kontrol diberi perlakuan dalam kegiatan proses belajarmengajar dengan menggunakan pembe-lajaran konvensional, sedangkan kelas X IPA ${ }_{1}$ yang merupakan kelas eksperimen yang diberikan proses kegiatan belajar-mengajar dengan menggunakan model pembelajaran Argument Driven Inquiry (ADI).

Hasil yang diperoleh dalam penelitian sebelum dilakukan perlakuan (pretest) didapat kan nilai rata-rata masing kelas dan nilai simpangan baku. Adapun nilai rata-rata siswa dalam pretes keterampilan berargumentasi ilmiah pada siswa di kelas eksperimen adalah 25,33 dan untuk kelas kontrol adalah 27,78 dan simpangan baku pada kelas eksperimen adalah 5,52 dan kelas kontrol adalah 5,22.

Sebelum dilakukan uji Homogenitas pretes dibantu dengan Software SPSS 21, maka untuk mengetahui data tersebut memiliki varians yang sama terlebih dahulu digunakan uji normalitas. Adapun nilai dari normalitas pada kedua kelas menggunakan uji KolomogrovSmirnov pada Software SPSS 21 dan nilai yang diperoleh adalah 0,086 pada kelas eksperimen dan 0,06 pada kelas kontrol. Syarat dalam mengetahui data tersebut berdistribusi normal adalah jika taraf signifikan $\alpha>0,05$ yang artinya 
bahwa data tersebut adalah berdistribusi normal, karena lebih besar dari 0,05 maka pada uji coba pretes pada kedua kelas yang diperoleh berdistribusi normal.

Selanjutnya jika kedua kelas memiliki data normal, maka selanjutnya dilakukan uji homogenitas dengan menggunakan Uji Levene test dengan menggunakan taraf signifikan 0,05 dan syarat pengujian jika nilai signifikan pada kolom lebih besar dari 0,05 maka populasinya mempunyai varians yang sama. Berdasarkan nilai yang diperoleh pada uji homogenitas di kedua kelas memiliki nilai signifikannya adalah 0,572 , karena $0,572>\alpha=0,05$, maka dapat disimpulkan bahwa siswa kelas kontrol dan kelas eksperimen berasal dari populasi-populasi yang memiliki varians sama atau dapat dikatakan bahwa kedua kelas homogen.

Hal yang dilakukan ketika selesai dalam uji normalitas dan uji homogenitas, langkah selanjutnya dilakukan dengan melakukan uji kesamaan varians dan nilai rata-rata dilakukan dengan uji Independent sample t test mengguna kan Software SPSS 21, Adapun syarat untuk mengetahui apakah memiliki perbedaan atau persamaan pada data adalah jika nilai signifikan (sig-2-tailed), jika sig lebih kecil daripada 0,05 maka terdapat perbedaan pada kedua kelas, sedangkan jika lebih besa daripada nilai sig 0,05 maka memiliki kesamaan di kedua kelas. Setelah dilakukan pengolahan data dengan uji Independent sample $t$ diperoleh data 0,084 adapun maksudnya adalah nilai data yang diperoleh lebih besar dari pada 0,05 maka terdapat kesamaan dalam keterampilan berargumentasi ilmiah pada siswa.

Setelah dilakukan pengolahan data untuk pretest maka selanjutnya dilakukan pengolahan data untuk postest dalam mengetahui pengaruh model pembelajaran terhadap keterampilan berargumentasi ilmiah pada siswa. Adapun nilai yang diperoleh untuk nilai rata-rata dan simpangan baku adalah data rata-rata postes kemampuan argumentasi di kelas eksperimen adalah 76,06 dan pada kelas kontrol adalah 71,00 dan simpangan baku pada kelas eksperimen 8,13 dan kelas kontrol adalah 9,62. Berdasarkan data yang diperoleh tersebut menunjukkan bahwa terdapat peningkatan pada kelas eksperimen dimana nilai kelas eksperimen lebih tinggi dibandingkan dengan nilai rata-rat pada kelas kontrol.

Hasil output uji normalitas varians dengan menguji Kolomogrov-Smirnov, adapun nilai dari signifikan pada uji normalitas ini diperoleh kelompok ataupun kelas eksperimen diperoleh 0,193 dan kelompok atau kelas kontrol diperoleh 0,104 . Dari hasil uji coba tersebut, karena nilai signifikansi pada kelas eksperimen dan kelas kontrol lebih besar dibandingkan dengan 0,05 maka dapat disimpulkan bahwa kedua kelas tersebut memiliki data berdistribusi normal.

Langkah selanjutnya setelah diperoleh nilai normalitas pada postes maka uji yang dilaksanakan adalah uji homoge-nitas dengan menggunakan uji Levene. Adapun nilai signifikansi yang diperoleh setelah dilakukan pengolahan data adalah 0,208 , karena nilai signifikansinya lebih besar dari 0,05 , oleh sebab itu dapat dikatakan bahwa populasi pada kelas eksperimen dan populasi pada kelas kontrol memiliki varians yang sama atau dengan kata lain bahwa kedua kelas homogen.

Adapun untuk menganalisis pengaruh model pembelajaran terhadap keterampilan berargumentasi siswa dengan menggunakan model pembelajaran Argument-Driven Inquiry (ADI) dan pembelajaran konvensional dapat dilihat pada Tabel 2 dibawah ini :

Tabel 2. Independent Samples Test

\begin{tabular}{|c|c|c|c|}
\hline \multirow[b]{2}{*}{ Kelerampilan Agumentasi } & \multicolumn{3}{|c|}{ for Equality of thest for Equality of Means } \\
\hline & F Sig. & & $\begin{array}{ll} & \text { Sig. (2- } \\
\text { if } & \text { tailed) }\end{array}$ \\
\hline Eiqual parancoss assumed & $1,622 \quad 208$ & $-2,353$ & $58 \quad, 022$ \\
\hline Equal variances not assumed & & $-2,353$ & 56,535 \\
\hline
\end{tabular}

Berdasarkan Tabel 2, nilai Sig (2-tailed) adalah 0,022 , karena nilai signifikan dibawah 0,05 maka ada perbedaan dnilai dari perolehan statistik atau signifikan pada probabilitas 0,05 . Hal ini berarti setelah dilakukan penelitian dengan menerapkan model pembelajaran Argument-Driven Inquiry pada kelas eksperimen, maka ada pengaruh terhadap keterampilan berargumentasi ilmiah pada siswa.

Hasil penelitian yang sudah diperoleh data-datanya, selanjutnya yang dilakukan untuk menganalisis bagaimana perbandingan dari data pretes dan postes pada kelas yang menggunakan model pembelajaran Argument-Driven Inquiry (kelas eksperimen) kemudian dilakukan analisis untuk melihat perbandingan data pretes dan postes pada kelas eksperimen dan kelas kontrol. Gambar.2 memperlihatkan perbandingan nilai keterampilan argumentasi ilmiah pada siswa kelas yang diajarkan dengan pembelajaran 
konvensional (kelas kontrol) dan kelas yang diberikan perlakuan model pembelajaran Argument-Driven Inquiry (kelas eksperimen) menunjukkan adanya nilai rata-rata keteramapil an berargumentasi pada siswa pada saat sebelum dan sesudah dilakukan perlakuan mengalami peningkatan, dimana nilai pada kelas kontrol naik menjadi 42,88, dan pada kelas eksperimen nilai rerata siswa naik menjadi 50,73. Dari data yang diperoleh maka dapat disimpulkan terjadinya peningkatan nilai rata-rata siswa pada keterampilan argumentasi ilmiah siswa kelas yang diberikan perlakukan dengan model pembelajaran argument driven inquiry lebih tinggi dibandingkan dengan pembelajaran yang diberikan perlakuan konvensional pada kelas kontrol.

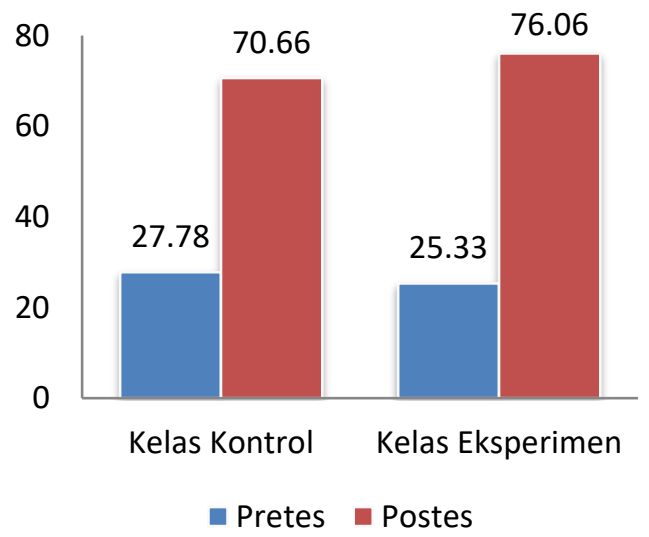

Gambar 2. Nilai pretes-postes Keterampilan Argumentasi Pada Siswa dengan menggunakan Kelompok di Kelas Kontrol dan Kelas Eksperimen

Adapun kelas yang digunakan dalam mendapatkan nilai untuk pretest dan postest dimana terdapat kelas kontrol yaitu kelas yang menggunakan pembelajaran konvensional dan kelas eksperimen yaitu kelas yang menggunakan Argument-Driven Inquiry. Berdasarkan Gambar 2 diatas diperoleh bahwa keterampilan argumentasi ilmiah siswa pada kelas eksperimen dengan melakukan pembelajaran yang menggunakan model pembelajaran Argument Driven Inquiry lebih tinggi dibandingkan pada kelas kontrol kegiatan belajar-mengajar meng gunakan pembelajaran konvensional yaitu 76,06 dan 70,66 dari hasil rata-rata tersebut dapat diperoleh setelah melakukan penelitian terdapat perbedaan antara keterampilan argumentasi ilmiah siswa antara kelas kontrol dengan kelas eksperimen hal ini , jika dilihat dari aktivitas dalam pelakasanaan yang dilakukan oleh guru dalam melakukan pembelajaran Argument Driven Inquiry (ADI) sangat baik. Hal ini memperlihatkan dimana guru sanggup mengatur kelas dalam kegiatan pembelajaran di lingkungan kelas sesuai dengan yang diterapkan dalam rencana pelaksanaan pembelajaran (RPP). Di samping itu juga dengan telah terlaksananya pembelajaran dengan menggunakan model pembelajaran Argument Driven Inquiry (ADI tidak terlepas dari aktivitas siswa.

Pembelajaran dengan penggunaan model pembelajaran Argument Driven Inquiry (ADI telah dilakukan oleh siswa melalui aktivitas yang sejalan dengan rencana pelaksanaan pembelajaran (RPP) yang sudah dipersiapkan. Kemampuan argumentasi ilmiah siswa jika dilihat dari semua segi pada indikator meningkat sesuai dengan pendapat yang dikemukakan oleh Kurniasari dan Setyarsih (2017). Dalam melakukan pembelajaran ketika siswa dilakukan uji coba pada saat saat sebelum dilakukan perlakuan (pretest), dalam pencapaian yang diperoleh siswa hanya bisa pada level 1 dan level 2, ada juga sebagian dari siswa masih berada pada level dibawah 1 . Setelah diberikan perlakuan pada siswa dapat mencapai level 3 pada saat posttest. Pembelajaran dengan model Argument-Driven Inquiry (ADI) mendapat respon yang positif dari siswa.

Penggunaan model pembelajaran Arugument-Driven Inquiry juga dapat meningkatkan siswa dapat memberikan sanggahan terhadap suatu pernyataan berdasarkan buktibukti yang didapatkan dari kegiatan hasil pembelajaran, dan memberikan kesimpulan terhadap suatu masalah tersebut. Sejalan dengan pendapat yang dikemukakan oleh Sampson dan Gleim (2009) pada tahap penyusunan argumen tentatif, siswa dituntut supaya bisa memberikan suatu penyatan dalam klaim, mendukung suatu ide atau pendapat dengan pemberian fakta-fakta yang sesuai, penyelidikan ilmiah yang dilaksana kan harus sesuai dengan bukti-bukti yang mendukung dan dapat memberikan penjelasan. Kemudian pada diskusi interaktif argumentasi, hasil penelitian kelompok lain dimana dalam hal ini siswa diberikan waktu atau kesempatan untuk memberikan suatu pendapat, dorongan, saran atau kritik, melakukan perbaikan dari kesimpul an yang diperoleh, serta penejelasan atau dugaan. 
Berdasarkan hasil penelitian tersebut dengan penggunakan kegiatan belajar-mengajar dengan penerapan model pembelajaran Argument-Driven Inquiry lebih tinggi dibandingkan dengan kegiatan belajar-mengajar dengan penerapan konvensional karena dapat menghasil kan suatu kualitas berkomunikasi ataupun berargumentasi yang lebih baik yang mana dapat mempengaruhi cara siswa dalam ikut serta dalam berrgumentasi ilmiah dimana dalam hal ini siswa lebih disiplin dan teratur terhadap argumentasi yang telah disusun oleh siswa tersebut (Kurniasari dan Woro (2017); Sampson et al (2010); Zahara et al (2018)). Pencapaian yang diperoleh oleh siswa dalam keterampilan argumentasi dengan kegiatan pembelajaran pada model Argument Driven Inquiry (ADI) lebih tinggi jika dilihat dari siswa dengan kegiatan pembelajaran konvensional. Siswa yang me miliki pengetahuan akademik bawah pada saat dilakukan pembelajaran konvensional lebih tinggi jika dibandingkan dengan siswa yang akademik atas. Disamping itu jika digunakan pembelajaran Argument Driven Inquiry (ADI) siswa yang memiliki akademik atas lebih tinggi dalam pencapaian berargumentasi dibandingkan dengan siswa akademik bawah (Safira et al :2018).

Adapun untuk mengetahui keterampilan argumentasi siswa pada kelas eksperimen ketika melakukan percobaan di laboratorium dengan menggunakan keterampilan lisan dalam berargumentasi ilmiah diperoleh data pada Gambar 3. Berdasarkan indikatornya dimana menurut pendapat dari Toulmin (2003) yang mendefinisikan argumen sebagai pernyataan yang disertai alasan yang meliputi komponen klaim (claim), data (data), pembenaran (warrant), syarat (qualifer), dukungan (backing), dan sanggahan (rebuttal). Disini peneliti dalam melakukan keterampilan yang diterapkan dalam pembelajaran berupa percobaan di kelas eksperimen hanya menggunakan 5 indikator saja yaitu klaim (claim), data (data), pembenaran (warrant), syarat (qualifer), dukungan (backing), dan sanggahan (rebuttal).

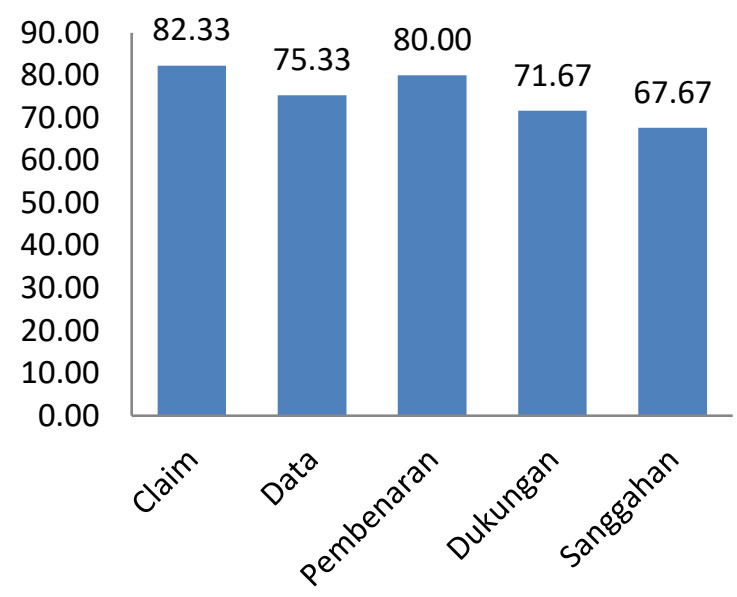

Gambar 3. Nilai Rata-rata Keterampilan Argumentasi Lisan Pada Kelas Percobaan (Eksperimen)

Gambar 2. Diatas menunjukkan bahwa kemampuan argumentasi lisan siswa tiap kelompok pada kelas eksperimen berbeda-beda. Dimana pada indikator yang paling tinggi adalah claim dimana disini siswa mengandung argumentasi antara satu klaim dengan berlawanan claim lainnya yaitu 82,33 kemudian disusul oleh pembenaran 80 dan data 75,33. Setelah itu indikator dukungan 71,67 dan sanggahan 67,77 .

Rata-rata keterampilan argumentasi lisan kelompok kelas eksperimen mencapai level 3, dimana siswa dapat menyampaikan kritik atau argument yang berlawanan dari data pendukung dan juga diberikan sanggahan melalui suatu rangkaian pernyataan (claim).

Adanya peningkatan level argumentasi setelah penerapan model Argument-Driven Inquiry (ADI) sejalan dengan hasil penilaian dengan lembar asesmen kinerja argumentasi, pada saat proses sesi argumentasi yang mana kemampuan argumentasi siswa meningkat karena siswa menemukan sendiri bukti dari hasil penyelidikan. berdasarkan pendapat yang di kemukan oleh Sampson et al (2009) pada tingkatan ini siswa dapat dibantu dalam mempelajari bagaimana aspek sosial dalam argumentasi ilmiah dengan memberikan bukti, menselaraskan dengan teori atau hukum ilmiah, hal ini dapat didesain agar siswa menjadi kritis melalui suatu produk (klaim atau argumen), proses (metode), dan konteks (landasan teori) dari suatu inquiry. 
Hasil penelitian yang diperoleh setelah dilakukan analisis data, maka peneliti dapat membuat suatu kesimpulan bahwa terdapat pengaruh keterampilan argumentasi ilmiah siswa dengan menggunakan model pembelajaran Argument Driven Inquiry (ADI) dimana adanya peningkatan keterampilan argumentasi ilmiah pada siswa dengan model pembelajaran Argument Driven Inquiry (ADI) lebih tinggi dibandingkan dengan menggunakan pembelajaran konvensional yaitu dimana pada kelas eksperimen memperoleh data peningkatan keterampilan argumentasi siswa 76.06 dan kelas kontrol 70,66.

Hasil penelitian ini masih belum optimal karena dalam rata-rata keterampilan siswa dalam kategori dukungan dan sanggahan masih kurang, hal ini disebabkan guru sebagai fasilitator dalam pembelajaran belum pernah menerapkan model pembelajaran Argument-Driven Inquiry (ADI) sehingga peserta didik masih kesulitan dalam proses pembelajaran yang menurut mereka masih baru.

\section{DAFTAR PUSTAKA}

American Association Of Colleges For Teacher Education. (2010). 21st Century

Knowledge And Education. New York: National Education Association

Amin, A Muh. dan Corebima AD. (2016). Analisis Presepsi Dosen Terhadap Strategi Pembelajaran Reading Questioning and Answering (RQA) Dan Argument Driven Inquiry (ADI) Pada Program Studi Pendidikan Biologi Di Kota Makassar. Makassar: Seminar Nasional II Tahun 2016 Kerjasama Prodi Pendidikan Biologi FKIP dengan Pusat Studi Lingkunan dan Kependudukan (PLSK) Universitas Muhammadiyah Malang

Arikunto, Suharsimi. (2010). Dasar-Dasar Evaluasi Pendidikan Edisi Revisi. Jakarta: Bumi Aksara.

Duschl \& Osborne. (2002). Supporting And Promoting Argumentation Discourse In Science Education. Studies In Science Education. 38(1): 39-72.

Kementrian Pendidikan Dan Kebudayaan. (2013). Peraturan Menteri Pendidikan dan Kebudayaan Republik
Indonesia Nomor 65 Tahun 2013

Tentang Standar Proses

Pendidikan Dasar Dan Menengah.

Jakarta: Kemendikbud

Kemendikbud. (2016). Permendikbud Nomor

22 Tahun 2016 Tentang Standar

Proses Pendidikan Dan Menengah.

Jakarta: Kemendikbud.

Kurniasari, Ika Sakti, Woro Setyarsih. (2017).

Penerapan Model Pembelajaran

Argument Driven Inquiry (ADI) Untuk

Melatihkan Kemampuan Argumentasi

Ilmiah Siswa Pada Materi Usaha

dan Energi. Jurnal Inovasi

Pendidikan Fisika (JIPF ) 6 (03):171174

Marhamah, Ofi Shofiyatun Marhama1, Ilah

Nurlaelah, Ina Setiawati. (2017).

Penerapan Model Argument-Driven

Inquiry (ADI) dalam Meningkatkan

Kemampuan Berargumentasi Siswa

Pada Konsep Pencemaran Lingkungan

Di Kelas X SMA Negeri 1 Ciawigebang.

Quagga 9(2) : 46-54

Safira, Cherry Acerola, Neni Hasnunidah, Darlen Sikumbang. (2018). Pengaruh Model Pembelajaran Argument-

Driven Inquiry (ADI) Terhadap

Keterampilan Argumentasi Siswa

Berkemampuan Akademik Berbeda.

Indonesian Journal of Biology

Education 1(2): 46-51

Sampson, V. \& Gleim, L. (2009).

Argument-Driven Inquiry To

Promote The Understanding Of

Important Concepts \& Practices In

Biology. The American Biology

Teacher. 71(8): 465-472.

Sampson, V., Grooms, J. \& Walker, J.P. (2010). Argument-Driven Inquiry As A Way To Help Students How To Participate In Scientific argumentation And Craft Written Arguments: An Exploratory Study. USA: Wiley Peiodical Inc.

Sampson, V., Enderle, P., Grooms, J. \& Southerland, S. A. (2012). Using laboratory activities that emphasize argumentation and argument to help high school students learn how to engage in scientific inquiry and understand the nature of scientific 
inquiry. Indianapolis, ID: Paper presented at the annual International conference of the National Association for Research in Science Teaching (NARST).

Simon, S., Erduran, S. \& Osborne, J. (2006). Learning To Teach Argumentation: Research And Development In The Science Classroom. International Journal Of Science Education, 28: 235260.

Sukma, Wahyu G, Setiya Utari \& Muslim. 2015. Penerapan Model ArgumentDriven Inquiry dalam Pembelajaran IPA Untuk Meningkatkan

Kemampuan Argumentasi Ilmiah
Siswa SMP. Jurnal Pembelajaran MIPA. 20 (1): 32-37.

Toulmin, S. (2003). The Uses Of Argument. New York : Cambridge University Press.

Zahara, Intan Kamila, Undang Rosidin, Kartini Helina1 dan Neni Hasnunidah. 2018. Pengaruh Penerapan Model Argument-Driven Inquiry (Adi) Pada Pembelajaran IPA Terhadap Keterampilan Argumentasi Siswa Smp Berdasarkan Perbedaan Kemampuan Akademik. Jurnal Ilmu Fisika dan Pembelajarannya (JIFP) 2(2): 53-61 